\title{
ECOTOURISM AND COMMUNITY INVOLVEMENT: CHALLENGES AND STRATEGIES
}

\author{
Joseph P. D.* , P. Pakkeerappa**
}

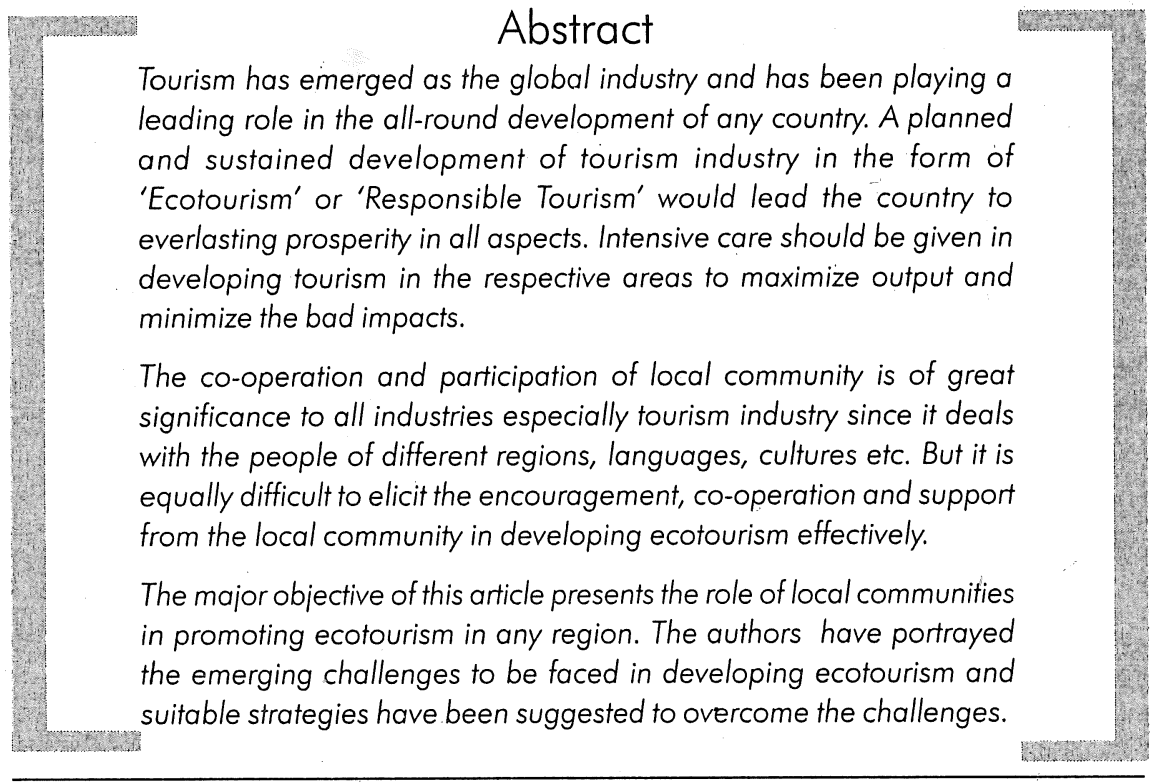

* Lecturer, Dept. of Business Administration, Mangalore University, Mangalagangotri.

** Professor \& Former Dean, Dept. of Business Administration, Mangalore University, Mangalagangotri. 


\section{Introduction}

Tourism has emerged as the global industry and has been playing a leading role in the all-round development of any country. Travel and Tourism is known to mankind from time immemorial, initially linked with trade and commerce and later diversified to a number of aspects such as religion, health, sports, conference, relaxation and so on. Tourism enables to shorten the distance between different continents and their people and to bring them under one umbrella irrespective of their caste, colour, and creed to build universal brotherhood.

Economic diversification and technological advancement have made tourism as the world's largest and fastest growing industry in terms of income generation and employment creation. Increased disposable income and development in the field of transport and communication have stimulated this industry to widen its horizon to every corner of the world. The enormous potential behind developing tourism showed the "Green Light' for many countries to recognize tourism as an instrument for all-round economic growth with the co-ordination and co-operation of different constituent bodies like Tourism Ministry, NTOs etc. Studies have proved that Tourism is an effective engine for generating employment, earning revenue and foreign exchange, enhancing environment, preserving culture, tradition and thereby facilitating dramatic development of the country. Because of its multiplier effect, the development of tourism, directly and indirectly adds more and more people in the process of tourism development. It is predicted that, by 2010 , tourism industry in India will create 7. million new jobs, may contribute Rs. 1,30,000 crore in capital investment and may have $7 \%$ share in GDP.

The vital statistics relating to Indian tourism published in the year 2007 amply demonstrate that the industry is growing at a very faster rate.

Important Facts about Tourism, 2007.

(Source: Dept. of Tourism, Govt. of India)

\begin{tabular}{|l|l|l|}
\hline \multirow{3}{*}{ India } & No. of Foreign Tourist Arrivals & 5.08 Million \\
& Annual Growth Rate & $14.3 \%$ \\
& Foreign Exchange Earnings from Tourism & Rs. 44360 Crores \\
& Annual Growth Rate & $13.7 \%$ \\
\hline \multirow{3}{*}{ orld } & No. of International Tourist Arrivals & 903 Million \\
& Annual Growth Rate & $6.6 \%$ \\
& International Tourism Receipts & $\$ 856$ Billion \\
& Annual Growth Rate & $15.4 \%$ \\
\hline
\end{tabular}




\begin{tabular}{|c|c|c|}
\hline $\begin{array}{l}\text { Asia \& the } \\
\text { Pacific } \\
\text { Region }\end{array}$ & $\begin{array}{l}\text { No. of International Tourist Arrivals } \\
\text { Annual Growth Rate } \\
\text { International Tourism Receipts } \\
\text { Annual Growth Rate }\end{array}$ & $\begin{array}{l}184.3 \text { Million } \\
10.4 \% \\
\$ 188.9 \text { Billion } \\
20.7 \%\end{array}$ \\
\hline $\begin{array}{l}\text { India in } \\
\text { the World }\end{array}$ & $\begin{array}{l}\text { India's share to International Tourist Arrivals } \\
\text { India's rank in International Tourist Arrival } \\
\text { India's share to International Tourism Receipts } \\
\text { India's rank in International Tourism Receipts }\end{array}$ & $\begin{array}{l}0.56 \% \\
42 \\
1.25 \% \\
20\end{array}$ \\
\hline $\begin{array}{l}\text { India in Asia } \\
\text { and the } \\
\text { Pacific } \\
\text { Region }\end{array}$ & $\begin{array}{l}\text { Share of India in Tourist Arrivals } \\
\text { India's Rank in Tourist Arrivals } \\
\text { India's share in Tourism Receipts } \\
\text { India's rank in Tourism Receipts }\end{array}$ & $\begin{array}{l}2.76 \% \\
11 \\
5.68 \% \\
6\end{array}$ \\
\hline
\end{tabular}

Even though tourism is the second highest foreign exchange earner of our country with about 5.3\% GDP contribution, a close perusal of the data depicted above reveals that the position of India in Global Tourism is much below, when compared to the geographical area and the multifaceted resources we have here in our country. Most of these potentials are untapped and the development is stereotyped which concentrates the developments in the selected areas only. Compared to some small countries, our contribution to the world tourism, still remain below $1 \%$. Those countries with limited resources such as UAE, Singapore, Switzerland etc. are overtaking India with their systematic planning and development of the tourism industry. Dr. Siddharatha Shankar, in his book, noted that "In 1984 India ranked $34^{\text {th }}$ while China was $44^{\text {th }}$ position in the tourism ranking. According to one estimate of WTO, in China foreign tourist arrivals may increase by 100 million while in India, it would increase from 3.28 million to 9 million by 2019-2020". It is the time we think about our shortcomings and to come up with the better steps for the maximum utilization of tourism resources.

Today, Indian tourism industry is facing high competitions from the rest of the world, particularly from the Asian countries. Every country is trying to be No. 1 by identifying and developing something new and unique for the everlasting demands of the visitors. This attitude of tourism providers make the destination as 'Amalgam Destination', (Adestination with varieties of attractions and facilities to cater for the needs of all type of visitors) such as Dubai, London, Singapore etc. High competition in tourism industry paved the way for the providers to use sophisticated methods of marketing like Virtual Tour, E-brochures, Websites etc. to inform and persuade the 
people towards their destination and thereby offering a full fledged group of service as part of maximizing visitor satisfaction.

According to the present situation, tourism industry of our country is going through a lot of challenges and threats from internal and external factors. World-wide terrorist attacks, global economic slowdown, climatic and environmental changes, Naxalism and Extremism badly affected the industry and it has entered as virus to the mainstream of our tourism sector. These factors have made the people to rethink while they take a decision to travel to a particular place. Because of these reasons, many vibrant destinations in our country still remain unexplored and the tourist entry to such area has been restricted. For instance, Kashmir, being the most wonderful destination in our country, we are not in a position to market it to the inbound and domestic tourists owing to the terrorism menace. It is not because the God has not graced our nation with enormous natural gifts but the activities of people make it useless.

\section{Ecotourism}

It is one among the most effective form of sustainable development in tourism to maximize the output and minimize the negative impacts of tourism development through preventing the deterioration of environmental and cultural values. The International Ecotourism Society defines ecotourism as "Responsible travel to natural areas that conserve the environment and improves the well being of local people". This means that the promoters of the ecotourism are bound to follow the following principles:-

- Minimizing the negative impacts

- Creating environmental and cultural awareness and respect.

- Offering true experiences for the guests and the hosts.

- Guaranteeing direct financial benefits for the conservation.

- Involving the local people in the decision making process.

- Support international human rights and labour agreements.

- Enriching sensitivity to host country's political, environmental and social climate.

The presence of the issues such as deforestation, pollution (Water, Air, Noise and Visual), disturbance and destruction of wildlife and marine life, demonstration effect, commercialization of culture, increase in cost of living, creating an imbalance in 
the social structure, etc. and their impact on tourism has led to the emergence of the concept of ecotourism and its practice by several countries across the globe.

Today, environmental destruction and social changes have become a global issue which arises through the barbarian activities of human beings. Major portion of the land area have been occupied by concrete forests which ultimately leading to Global Warming, Rise in sea level, Pollutions etc. Countries like Thailand and Philippines have experienced the bitter side of promoting Mass Tourism irrespective of its carrying capacity. In order to maintain the sustainability in tourism, a proportionate and balanced development is inevitable. This fact has opened the eyes of many tourism promoters in the world and they have made special legislation and amendments to make sure that an environment and culture friendly tourism development is being taken place. For instance, Maldives - a small island nation in the Indian Ocean, has strictly warned the promoters and the developers of tourism that only $30 \%$ of the chosen area should be built and rest of the space should be kept as it is, while they make any type of tourism projects.

\section{Role of Local Community in Ecotourism Development}

The co-operation and participation of local community is of great significance to all industries especially to tourism industry since it deals with the people of different regions, languages, cultures etc. But it is equally difficult to elicit the encouragement, co-operation and support from the local community in developing ecotourism effectively.

There is an integral role to be played by the local community in various aspects of ecotourism. 'Responsible Tourism' - the latest origin in the field of ecotourism clearly defines the role of local community to make it sustainable. According to Responsible Tourism concept, it is not only the providers and tourists to take care of the environment and related features but the residents also have equal duty and responsibility to co-operate with the tourism process and protect their surroundings without destruction.

There are many instances in the history of tourism that the rude and inhospitable nature of the host community reduced the tourist traffic to the area. In the case of ecotourism which is promoted as rural tourism, farm tourism, agro tourism etc., the tourists are more likely to mingle with the host community and they are expecting full-fledged co-operation and assistance from the part of local community. The optimistic perception and dedicated involvement of local people is mandatory for the smooth and easy development of tourism at any destinations. Then only the widely used slogans of Indian tourism such as 'Incredible India', 'Atithi Devo 
Bhavah', 'God's Own Country', 'One State, Many Worlds' etc. would become meaningful.

The true spirit of tourism instruct the host people to "Welcome a Stranger and Send back a Friend' to foster the growth of tourism industry particularly with ecotourism projects. This initiative has to be taken mainly from the side of local people to make them comfortable throughout their entire travel and stay. The word 'Tourism' itself has laid down the foundation stone in the mind of a group of illiterate and rural people, as something bad and intolerable. This concept has to be changed by taking them all out of this shell of prejudices about tourists and tourism process. Otherwise it would be like visiting a relatives' house where we get an ill treatment and later we won't turn back to them to have an another visit and this message will be conveyed to others also.

Most of the local people are unaware about the importance of developing and promoting tourism in their respective region. There are a series of benefits and advantages accompanied by the tourism development at a particular region for their people directly and indirectly. The major ones are as follows:

- Creation of vast employment potentials directly and indirectly for all categories of people.

- Infrastructural development leading to regional prosperity.

- Increase in per capita income and national income.

- Exchange of cultural values and maintaining national and international relationship.

- Preservation of culture and heritage.

- Preservation of flora and fauna through ecotourism developments.

- Enrichment of educational values.

\section{Challenges}

The following problems or challenges hinder the growth and development of tourism in general and ecotourism in particular and it also throw light on the reasons why the local community keep themselves away from the process of tourism development.

- The lack of initiatives and interest shown by the local people and tourism promoters in providing suitable accommodation facilities due to the social setup, remain as one of the biggest challenges in ecotourism promotion. 
- It is very difficult task to get voluntary and incessant co-operation from the local community in order to boost ecotourism due to the social constraints and limited awareness.

- Another major challenge is faced by the ecotourism promoters to convince and persuade the various social, political, religious, environmental and other organizations when developing ecotourism.

- The local people are not well versed in providing clear information regarding the different tourism potentials and related facilities available in their area when tourists arrive at different sports. This poses a challenge in promoting ecotourism.

- Another problem is most of our rural/village areas are not accessible and lack of basic infrastructure and support facilities like communication, roads, water supply, accommodation etc. This further requires the provision of money and credit to finance the activities by the tourism organizations and other bodies.

- Lack of safety and security is an another threat faced by the tourism promoters due to the factors such as communalism, regionalism, terrorism, extremism etc.

- Most of our destinations are not well maintained and clean to cope up with the standard of foreign tourists.

- Our local people are not able to fully mingle with the tourists due to the communication gap, cultural differences and so on. This keeps them away from being so much hospitable.

\section{Strategies}

In order to tackle the above challenges, the following strategies can be adopted by which the community participation could be invited to make the concept of ecotourism more meaningful.

- There is an urgent need to enhance the hospitable attitude among the local people in the society. The local people should have concern and healthy relations with the tourists who visit different destinations, for which some awareness programs could be conducted with the supervision of local tourism bodies.

- The challenge of getting co-operafion from the society members can be met by providing adequate information on tourist attractions to the visitors by the host community. 
- The local people should come forward in providing safety and security and create tourist friendly environment in order to boost the ecotourism and the external hindrance can be prevented with the help of some special task force.

- The challenge of accommodation facilities can be overcome by requesting the local people to provide accommodation for the tourists in the form of home stays, farm houses, outhouses, guest rooms etc. and uphold the concept of 'Atithi Devo Bhavah', for which the government should provide some financial help in the form of loans, grants etc.

- We can develop ecotourism by preserving the natural environment by sharing the responsibility among the tourists, providers and the local people. Some strict legislation can be enforced against its violation.

- The challenge of neatness and cleanliness can be solved by maintaining the premises very well and tidy. There should be periodic inspection and supervision to keep the premises neat and clean.

- Greater emphasis should be given to the issue of real culture without any deterioration followed in the region.

- In order to have very effective participation by the local people, they can be encouraged to make and sell handicrafts and involve in selling brochures, magazines and souvenirs which carry information about tourist attractions.

\section{Conclusion}

A planned and sustained development of tourism industry in the form of 'Ecotourism' or 'Responsible Tourism' would lead the country to everlasting prosperity in all aspects. Utmost care to be given in developing tourism in the respective areas to maximize output and minimize the bad impacts. In order to handle this situation, the best alternative is the aggressive promotion of 'Ecotourism' projects in all spheres of tourism development through which the destination can ensure a tourism industry which is (a) environment friendly (b) minimum negative impacts, (c) local community participation and (d) more sustainable. 


\section{References}

D.S Bhardwai and Team(2006), International Tourism - Issues and Challenges, Kanishka Publications, New Delhi.

www.tourisminindia.com- Website of Dept. of Tourism, Govt. of India, last accessed on 25-11-08.

www.ecotourism.org- International Eco Tourism Society, last accessed on 25-11-08.

www.sustainabletravel.com- Sustainable Travel international, last accessed on 25-11-2008.

'Atna', Journal of Tourism Studies, Christ University, volume 3 (2008).

Articles Referred as follows:

1. Responsible tourism by Vinodan $A$

2. Ecotourism and sustainability by Shekar Naik and Puttanna

3. Community participation and visitor satisfaction for ecotourism by Sampad Kumar Swain, Bivraj Bhusan and Bagri.

Anurag Dugar, Promotion of Tourism (Challenges and Opportunities for India). 